\title{
Regulation of Brain-derived Neurotrophic Factor and Nerve Growth Factor mRNA in Primary Cultures of Hippocampal Neurons and Astrocytes
}

\author{
Francisco Zafra, Dan Lindholm, Eero Castrén, Jukka Hartikka, and Hans Thoenen \\ Department of Neurochemistry, Max Planck Institute for Psychiatry, 8033 Planegg-Martinsried, Germany
}

Brain-derived neurotrophic factor (BDNF) and NGF are both expressed by neurons in the hippocampus. In previous studies, it has been demonstrated that both BDNF and NGF mRNA levels are regulated by neuronal activity. Upregulation is predominantly regulated by the glutamate (NMDA and nonNMDA receptors); downregulation, predominantly by the GABA system (Zafra et al., 1990, 1991). In neuronal cultures of the rat hippocampus, potassium depolarization and kainic acid-mediated increases in BDNF and NGF mRNA were eliminated in a dose-dependent manner by the calcium channel blocker nifedipine. Conversely, calcium ionophores (BayK8644 and lonomycin) augmented BDNF and NGF mRNA levels by a calmodulin-mediated mechanism. In view of the fact that many potential modulators (conventional transmitters and neuropeptides) of neuronal and astrocytic BDNF and NGF mRNA synthesis may act via the adenylate cyclase system, we studied the effect of forskolin, an activator of adenylate cyclase. Indeed, forskolin enhanced the effects of calcium ionophores and kainic acid on BDNF and NGF mRNA levels. Cytokines, such as interleukin- 1 and transforming growth factor- $\beta 1$, which have previously been shown to increase NGF mRNA markedly in astrocytes, were without effect on neuronal BDNF and NGF mRNA levels. In contrast to neuronal cultures, where the regulation of BDNF and NGF mRNA was generally very similar, the regulation in astrocytes was distinctly different. All the cytokines that produce a marked increase in NGF mRNA were without effect on astrocyte BDNF mRNA levels, which under basic conditions were below the detection limit. However, norepinephrine produced a marked elevation of BDNF mRNA in astrocytes, an effect that was further enhanced by glutamate receptor agonists. In contrast, the response of NGF mRNA under the same culture conditions (low-serum medium) did not respond either to norepinephrine or to forskolin. However, the responsiveness of NGF mRNA in astrocyte cultures for CAMP is very much dependent on culture conditions.

The detection of new members of the NGF gene family (referred to as neurotrophins) has resulted in the rapid accumulation of information on the spectrum of their biological actions, regional

\footnotetext{
Received May 1, 1992; revised June 29, 1992; accepted July 1, 1992.

F.Z. was a recipient of EMBO long-term fellowship. E.C. is a fellow of the Alexander von Humboldt Foundation. We thank Dr. Tony Hughes and Ms. Lorraine Bale for linguistic revision.

Correspondence should be addressed to Hans Thoenen, Max Planck Institute for Psychiatry, Department of Neurochemistry, Am Klopferspitz 18A, 8033 Planegg-Martinsried, Germany.

Copyright (c) 1992 Society for Neuroscience $0270-6474 / 92 / 124793-07 \$ 05.00 / 0$
}

distribution, cellular localization, and developmental expression (see Barde, 1991; Thoenen, 1991). Besides completing the spectrum of biological actions of neurotrophins and identifying and characterizing their receptors, the elucidation of the regulation of their synthesis is essential for a comprehensive understanding of the physiological functions of the neurotrophins.

In the CNS, neurotrophins [NGF, brain-derived neurotrophic factor (BDNF), and neurotrophin-3 (NT-3)] are predominantly expressed in neurons. However, there are marked differences in their pattern of distribution and time course of their developmental expression (Ernfors et al., 1990a,b; Hofer et al., 1990; Maisonpierre et al., 1990; Phillips et al., 1990; Wetmore et al., 1990). In previous studies, we have shown that both NGF and BDNF $m$ RNA are regulated by neuronal activity predominantly by the glutamate and GABA systems (Zafra et al., 1990, 1991). Preliminary tissue culture experiments suggested that other transmitter systems and neuropeptides are also involved in the regulation of the neuronal synthesis of BDNF and NGF (Zafra et al., 1990).

Although the main sites of NGF expression in the CNS are specific populations of neurons (Ayer-LeLièvre et al., 1988; Whittemore et al., 1988; Gall and Isackson, 1989; Bandtlow et al., 1990; Ernfors et al., 1990b), the first reports on the regulation of NGF synthesis in the CNS referred to astrocytes in culture (Lindsay, 1979; Furukawa et al., 1986). The role played by these cells under physiological conditions is unclear, since in situ hybridization experiments have been unable to provide evidence for the substantial expression of neurotrophins in non-neuronal cells of the CNS under physiological conditions (Ayer-LeLièvre et al., 1988; Whittemore et al., 1988; Gall and Isackson, 1989; Bandtlow et al., 1990; Ernfors et al., 1990b). However, it is possible that astrocytes have a more important role under pathophysiological conditions. As a consequence of tissue damage, regulatory mechanisms, which are similar to those shown to regulate NGF synthesis in cultured astrocytes (Furukawa et al., 1986; Spranger et al., 1990; Lu et al., 1991; Yoshida and Gage, 1991), may come into play.

As a first step toward understanding the regulation of the synthesis of neurotrophins in integrated intact systems, we compared the regulation of NGF and BDNF mRNA in primary cultures of hippocampal neurons and cerebral astrocytes. Since the basal levels of BDNF mRNA in hippocampal cultures are about 20-30 times higher than those of NGF mRNA (Hofer et al., 1990; Zafra et al., 1990, 1991), and as it seems that the mechanisms of regulation of NGF and BDNF mRNAs in neurons are generally very similar, the main emphasis of the present study was to determine the regulation of neuronal BDNF mRNA. To quantify the distinctly lower basal levels of NGF mRNA, it 


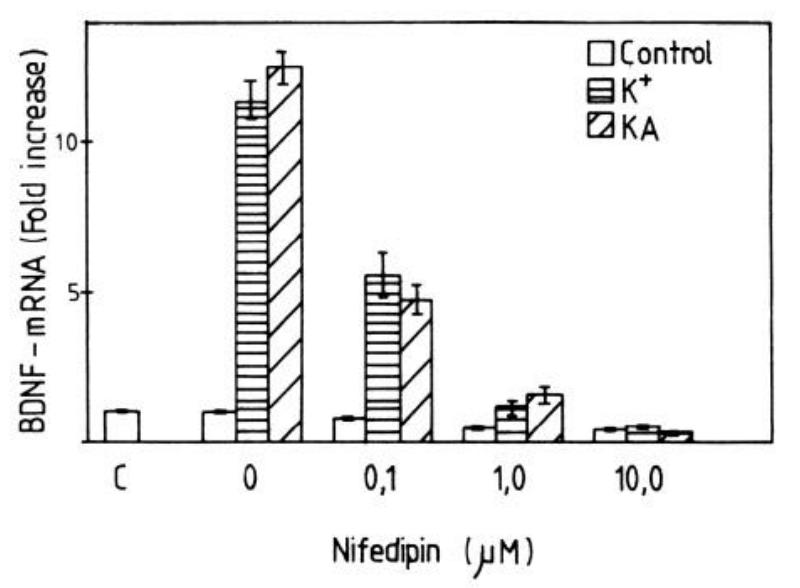

Figure 1. Effect of nifedipine on the potassium- and kainic acid-induced expression of BDNF mRNA in hippocampal neurons. Neurons were incubated for $3 \mathrm{hr}$ in the presence of $50 \mathrm{mM} \mathrm{KCl}$ or $30 \mu \mathrm{M}$ kainic acid and with the indicated concentrations of nifedipine. Cellular RNA was extracted and analyzed as described in Materials and Methods. Values are the mean \pm SEM of three different experiments.

was necessary to use a quantitative PCR method that has been previously described in detail (Zafra et al., 1990).

Calcium influx and the subsequent activation of calcium/ calmodulin-activated protein kinase(s) seem to play an essential role in the regulation of neuronal NGF and BDNF mRNA levels. Cytokines and growth factors that had previously been shown to increase NGF mRNA in primary cultures of astrocytes and that also enhance the production of NGF protein (Spranger et al., 1990; Yoshida and Gage, 1992) were without effect on BDNF mRNA levels, either in astrocytes or in hippocampal neurons. Thus, although the mechanisms that regulate the levels of neuronal BDNF and NGF mRNA are very similar, there are marked differences in the regulation of these mRNAs in astrocytes.

\section{Materials and Methods}

Materials. Interleukin-1 (IL-1) was obtained from Biogen Inc.; Dulbecco's Modified Eagle's Medium (DMEM) and fetal calf serum, from GIBCO; transforming growth factor- $\beta 1$ (TGF- $\beta 1$ ), from British Biotechnology; basic fibroblast growth factor (basic FGF), from Boehringer Mannheim; H7, W7, calmidazolium, nifedipine, and Bay-K8644, from Research Biochemicals Inc.; $\left(S_{p}\right)$ - and $\left(R_{p}\right)$-adenosine 3':5'-cyclic phosphorothioate $\left[\left(S_{p}\right)\right.$ - and $\left(R_{p}\right)$-cAMPS], from Biolog Life Science Institute (Bremen, Germany); and all other reagents, from Sigma.

Cell cultures. Neurons were prepared from hippocampus of 17-d-old rat embryos as previously described (Zafra et al., 1990). Briefly, the hippocampi were dissected and incubated for $20 \mathrm{~min}$ at $37^{\circ} \mathrm{C}$ in phosphate-buffered saline (PBS) in a solution containing $10 \mathrm{~mm}$ glucose, 1 $\mathrm{mg} / \mathrm{ml}$ albumin, $6 \mu \mathrm{g} / \mathrm{ml}$ DNase, and $12 \mathrm{U} / \mathrm{ml}$ papain. After washing, the cells were dissociated and collected by centrifugation, and resuspended in DMEM supplemented with $10 \%$ fetal calf serum. The cells were plated onto plastic culture dishes $\left(0.5 \times 10^{6}\right.$ cells per $35 \mathrm{~mm}$ dish) that were precoated with poly-DL-ornithine $(0.5 \mathrm{mg} / \mathrm{ml})$. The neurons were incubated in a serum-free medium lacking glutamate and containing the supplements as described by Brewer and Cotman (1989). Within a few days of incubation, the cultures exhibited a dense network of neurites, and the cells were usually used for the experiments at day 7 after plating. The neurons were incubated for various periods of time in the presence of growth factors and additions as indicated in the figure captions. BDNF mRNA levels were subsequently determined by Northern blot analysis, whereas a quantitative PCR method (see below) was used to estimate NGF mRNA levels in the neurons.

Astrocytes were prepared from newborn rat brains and purified as described earlier (Spranger et al., 1990). In brief, microglia and oligodendrocytes were removed from confluent primary glial cell cultures by a
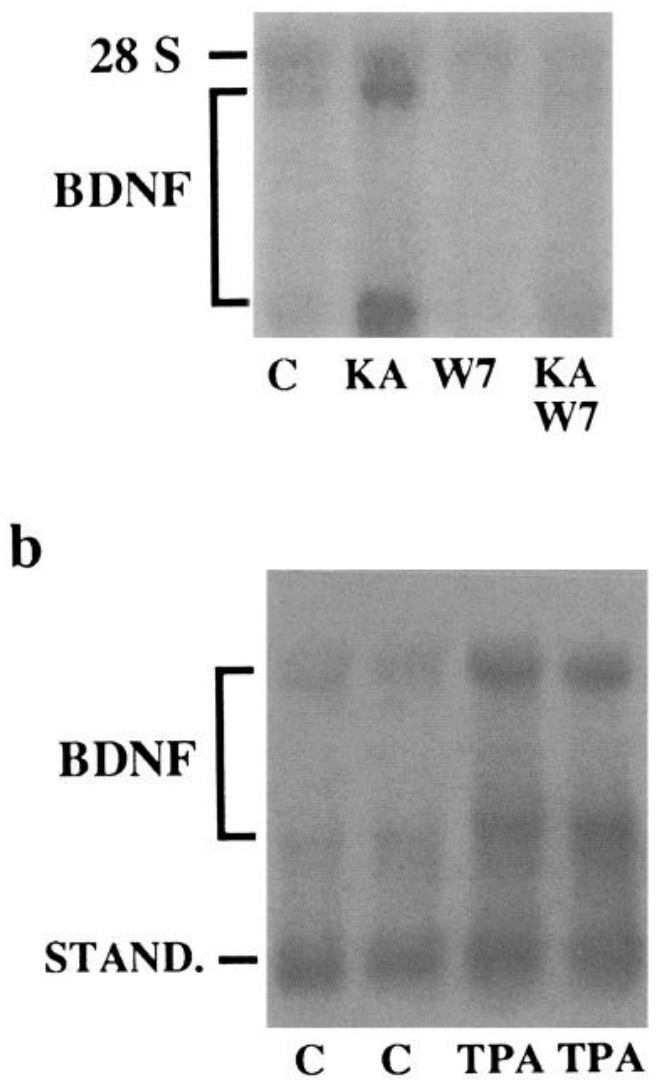

Figure 2. $a$, The effect of calmodulin inhibitor on BDNF mRNA in hippocampal neurons. Hippocampal neurons were incubated without additions $(C)$ or for $4 \mathrm{hr}$ with kainic acid $(K A ; 30 \mu \mathrm{M})$ in the presence or absence of a calmodulin inhibitor W7 $(1 \mu \mathrm{M})$. Total RNA was extracted and analyzed as described in Materials and Methods. The uppermost band represents 28S ribosomal RNA; the two lower bands (4 and $1.5 \mathrm{~kb}$ ) correspond to BDNF mRNA (Hofer et al., 1990). $b$, Sevenday-old hippocampal neurons were incubated for $3 \mathrm{hr}$ without $(C)$ or with protein kinase $C$ activator TPA $(100 \mathrm{ng} / \mathrm{ml})$. RNA was extracted and analyzed by Northern blot analysis.

shaking, and the astrocytes were replated onto plastic dishes. More than $95 \%$ of the cells were astrocytes as judged by staining with glial fibrillary acidic protein (results not shown). Astrocytes were incubated for $4 \mathrm{hr}$ after addition of various growth factors and agents, and the NGF and BDNF mRNA levels were determined by Northern blot analysis. cAMP levels were determined by a kit from Amersham and corrected for protein content.

RNA preparation and Northern blot analysis. RNA was extracted from cells as described by Chomczynski and Sacchi (1987) after the addition of a shortened [700 base pair (bp)] BDNF cRNA recovery standard (10 pg). Total cellular RNA was electrophoresed through a $1.3 \%$ agarose gel and transferred to Hybond $\mathrm{N}$ filters. After blotting, the filters were hybridized with a ${ }^{32} \mathrm{P}$-labeled cRNA probe specific for mouse BDNF (Zafra et al., 1990) as described earlier (Heumann and Thoenen, 1986). The filters were washed for $20 \mathrm{~min}$ at high stringency $(\mathrm{O} .2 \times$ salinesodium citrate at $75^{\circ} \mathrm{C}$ ) and exposed to $\mathrm{x}$-ray film. Autoradiography was performed for various periods of time depending on the intensity of the signals. A laser scanner (LKB) was used to estimate the amount of specific BDNF transcripts in the samples.

Quantitative PCR. Total neuronal RNA and a shortened NGF cRNA standard $(153 \mathrm{bp})$ were reverse transcribed into cDNA using a specific 3'-primer for NGF (24-mer, 5'TGTACGCCGATCAAAAACGCAGT GG-3') and avian myeloblastosis virus-reverse transcriptase. The DNA was subsequently subjected to 18 cycles of PCR using the above-mentioned primer and another 5'-primer (24-mer, 5'-CAGCATGGTGGA GTTTTGGCCTGT-3') (Zafra et al., 1990). The amplification was linear 


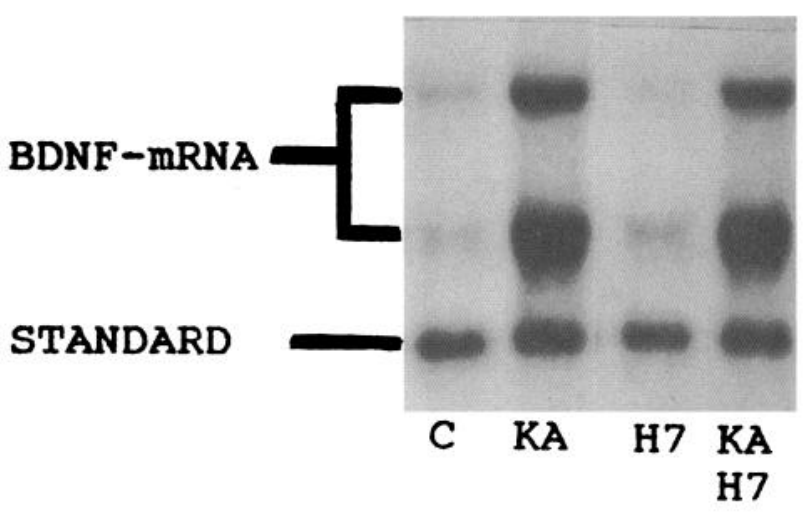

Figure 3. The effect of protein kinase $\mathrm{C}$ inhibitor on BDNF mRNA in hippocampal neurons. The neurons were incubated in the presence of $30 \mu \mathrm{M}$ kainic acid $(K A)$, with $25 \mu \mathrm{M}$ of protein kinase $\mathrm{C}$ inhibitor $\mathrm{H} 7$ or without additions $(C)$. RNA was extracted and analyzed by Northern blot analysis. The two upper bands are the two transcripts of BDNF, and the lower band $(700 \mathrm{bp})$ represents $5 \mathrm{pg}$ of the BDNF cRNA recovery standard (see Materials and Methods).

for up to 20 cycles. The products obtained ( $203 \mathrm{bp}$ for NGF and 153 bp for recovery standard) were run on a $3 \%$ NuSieve/agarose gel and blotted onto Hybond $\mathrm{N}+$ membranes (Amersham), and the filters were hybridized with a mouse NGF cRNA probe as described previously (Zafra et al., 1990).

\section{Results}

Role played by calcium in the increase of BDNF $m R N A$ levels in hippocampal neurons initiated by high potassium and kainic acid

In previous experiments, we have demonstrated that depolarization by high $\mathrm{KCl}(50 \mathrm{~mm})$ increased the levels of BDNF mRNA in cultured hippocampal neurons in a calcium-dependent manner (Zafra et al., 1990). Of all the transmitter substances or their analogs tested, kainic acid, a glutamate receptor agonist, had by far the greatest effect on BDNF mRNA in these cells. To investigate the role of calcium in more detail, nifedipine (a calcium channel blocker) was used on the one hand and activators of calcium channels on the other. As shown in Figure 1 , nifedipine impaired both the potassium- and the kainic acidmediated increase in BDNF mRNA in a concentration-dependent manner. Nifedipine not only interfered with the high $\mathrm{KCl}-$ and kainic acid-mediated BDNF mRNA increase but, at concentrations of 1 and $10 \mu \mathrm{M}$, also reduced the basal level of BDNF mRNA significantly $(P<0.05$; Fig. 1). Conversely, Bay-K8644, a compound that increases intracellular calcium concentration by opening L-type calcium channels, augmented BDNF mRNA levels in these neurons (see Fig. $4 b$, lower curve). W7, a calmodulin antagonist (Hidaka et al., 1991), blocked the kainateinduced increase in BDNF mRNA (Fig. 2a). Similar results were obtained with another calmodulin antagonist, calmidazolium (Van Belle, 1981) (results not shown). H7, a relatively specific inhibitor of protein kinase C (Hidaka et al., 1991), did not interfere with the kainic acid-mediated increase in BDNF mRNA in hippocampal neurons (Fig. 3). These data indicate that kainic acid induces BDNF mRNA in neurons by increasing intracellular calcium, which in turn acts through calcium/calmodulindependent protein kinases. However, protein kinase $\mathrm{C}$ may also have a role in the regulation of BDNF mRNA in cultured hippocampal neurons, because TPA, a phorbol ester, which activates protein kinase $C$, slightly increased BDNF mRNA levels in these neurons (Fig. $2 b$ ).
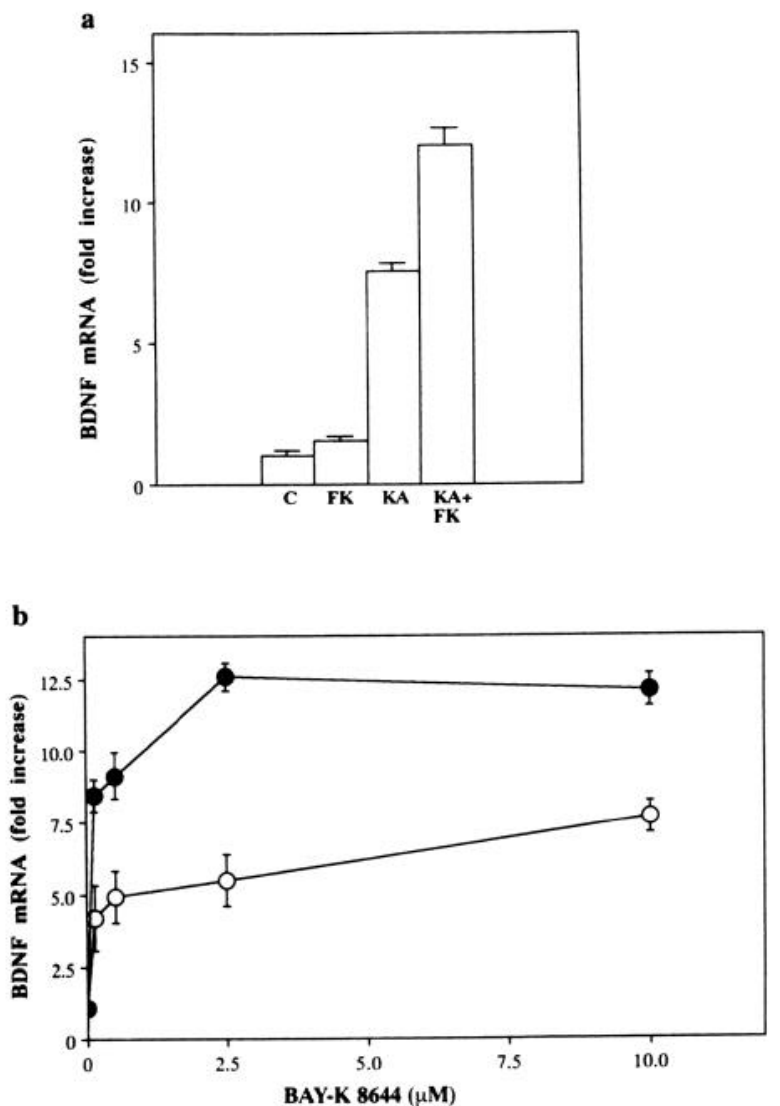

Figure 4. The effect of forskolin on the calcium- or kainic acid-induced expression of BDNF mRNA. $a$, Hippocampal neurons were incubated for $3 \mathrm{hr}$ in the presence of $50 \mu \mathrm{M}$ kainic acid $(K A)$, with $20 \mu \mathrm{M}$ forskolin $(F K)$, or with both drugs $(K A+F K)$. Values represent mean \pm SEM of three experiments. $b$, Hippocampal neurons were incubated for $3 \mathrm{hr}$ in the presence of the indicated concentrations of Bay-K8644 in the presence (solid circles) or absence (open circles) of $20 \mu \mathrm{M}$ forskolin. Total RNA was extracted and analyzed as described in Materials and Methods. Values represent mean \pm SEM of three experiments.

\section{Involvement of adenylate cyclase in the kainic acid-mediated increase in BDNF $M R N A$}

Forskolin, an activator of adenylate cyclase, alone increased BDNF mRNA only slightly, but it markedly enhanced the kainic acid-mediated BDNF mRNA increase in hippocampal neurons (Fig. 4a). Forskolin also increased the BDNF mRNA increase mediated by Bay-K8644 (Fig. $4 b$ ). Likewise, forskolin potentiated the effect of the calcium ionophore ionomycin in increasing BDNF mRNA levels in these neurons (data not shown). 8Bromo-cAMP and $\left(S_{p}\right)$-cAMPS, which also activate protein kinase A, produced similar effects as forskolin. The effect of $\left(S_{p}\right)$ cAMPS could be suppressed by a 20 -fold excess of $\left(R_{p}\right)$-cAMPS, an inactive stereoisomer (data not shown) (O'Brian et al., 1982). Thus, the effect of kainic acid on BDNF mRNA levels could involve both an increase in calcium influx and an activation of adenylate cyclase. To evaluate whether kainic acid does indeed affect adenylate cyclase activity, we studied the levels of cAMP in hippocampal neurons incubated with kainic acid. Table 1 shows that there is no significant increase in cAMP. Forskolin, a direct activator of adenylate cyclase, served as a positive control and resulted in a 5.5-fold increase in cAMP (Table 1). The absence of a direct action of CAMP in the kainic acid-initiated increase in BDNF mRNA was further established by the effect 
Table 1. cAMP content in primary cultures of hippocampal neurons

\begin{tabular}{ll} 
Additions & $\begin{array}{l}\text { cAMP } \\
\text { (pmol/mg protein) }\end{array}$ \\
\hline None & $12 \pm 6 \quad(n=4)$ \\
Forskolin $(20 \mu \mathrm{M})$ & $65 \pm 11(n=4)$ \\
Kainic acid $(30 \mu \mathrm{M})$ & $16 \pm 8 \quad(n=4)$
\end{tabular}

The neurons were incubated for $5 \mathrm{~min}$ in the presence of the indicated additions. cAMP was determined as indicated in Materials and Methods.

of $\left(R_{p}\right)$-cAMPS. This compound competes with cAMP in binding to the regulatory subunit of the protein kinase $A$, but does not activate it (O'Brian et al., 1982). $\left(R_{p}\right)$-cAMPS neither changed the basal level of BDNF mRNA nor affected the kainic acidmediated increase (data not shown). Thus, cAMP is not responsible for the kainic acid-mediated increase in BDNF mRNA levels in hippocampal neurons.

\section{Regulation of NGF $m R N A$ in hippocampal neurons}

Since the levels of NGF mRNA in cultures of hippocampal neurons are 20-30 times lower than those of BDNF mRNA, it was necessary to use a sensitive PCR method for the quantitative determination of NGF mRNA. As demonstrated in previous experiments, NGF mRNA levels in hippocampal neurons can be increased by depolarization with high $\mathrm{KCl}$ and kainic acid (Zafra et al., 1990, 1991). The responses of NGF mRNA are generally smaller than those of BDNF mRNA. Moreover, nifedipine, a calcium channel blocker, and EGTA abolished the kainic acid-mediated increase in NGF mRNA (data not shown) as demonstrated for BDNF (Fig. 1). Bay-K8644, which increases intracellular calcium levels by activating L-type calcium channels, elevated NGF mRNA in hippocampal neurons in a manner similar to that seen for BDNF mRNA (Figs. 4b, 5). Forskolin alone had a small (2.5-fold increase) effect on NGF mRNA levels, which was additive to that observed with Bay-K8644 (Fig. 5). This is in contrast to the actions seen on BDNF mRNA, where the effects of forskolin alone had little effect (Fig. 4a) but markedly potentiated the effect of Bay-K8644 (Fig. 4b) As seen above for BDNF mRNA (Fig. 2b), TPA also increased the levels of NGF mRNA in hippocampal neurons (Fig. 5).

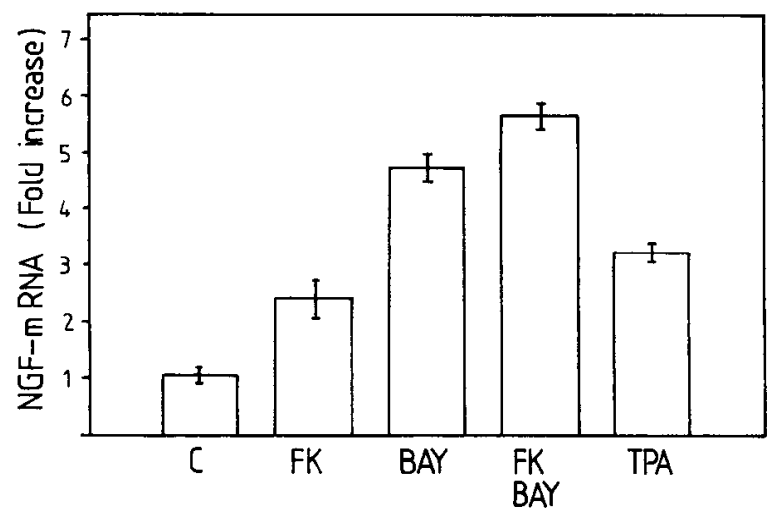

Figure 5. The effect of forskolin and increased calcium on NGF mRNA levels in hippocampal neurons. The neurons were incubated for $3 \mathrm{hr}$ in the presence of $20 \mu \mathrm{M}$ forskolin $(F K)$ and $1 \mu \mathrm{M}$ Bay-K8644 $(B A Y)$ or with both agents together $(F K B A Y)$. In some cultures, the phorbol ester TPA $(100 \mathrm{ng} / \mathrm{ml})$ was used. RNA was extracted and NGF mRNA levels were determined by the quantitative PCR method as described in Materials and Methods. The values represent means \pm SEM $(n=3)$.
Table 2. Effect of growth factors and cytokines on BDNF mRNA levels in hippocampal neurons

\begin{tabular}{lcc} 
Addition & Amount & $\begin{array}{c}\text { BDNF mRNA } \\
\text { (\% of controls) }\end{array}$ \\
\hline None & & $100 \pm 4$ \\
IL- $1 \alpha$ & $30 \mathrm{U} / \mathrm{ml}$ & $103 \pm 7$ \\
IL-1 $\beta$ & $30 \mathrm{U} / \mathrm{ml}$ & $97 \pm 7$ \\
TGF- $\beta 1$ & $2 \mathrm{ng} / \mathrm{ml}$ & $110 \pm 6$ \\
PDGF & $5 \mathrm{ng} / \mathrm{ml}$ & $107 \pm 5$ \\
EGF & $5 \mathrm{ng} / \mathrm{ml}$ & $102 \pm 6$ \\
bFGF & $5 \mathrm{ng} / \mathrm{ml}$ & $94 \pm 4$
\end{tabular}

The neurons were incubated for $4 \mathrm{hr}$ in the absence or presence of various growth factors in the concentrations indicated. The levels of BDNF mRNA were determined by Northern blot analysis (sce Materials and Methods). The values represent the means \pm SEM of three or more determinations. PDGF, platelet-derived growth factor.

\section{Effect of cytokines on NGF and BDNF mRNA levels in hippocampal neurons}

Previous experiments have demonstrated that a number of cytokines produce an increase in the levels of NGF mRNA and NGF protein in primary cultures of rat astrocytes (Lindholm et al., 1990; Spranger et al., 1990; Lu et al., 1991; Yoshida and Gage, 1991, 1992). In view of the fact that these molecules are expressed in brain cells (neurons and/or glial cells) after damage of neuronal tissue, it was of interest to see whether the same molecules, which induce NGF mRNA in astrocytes, also affect neuronal BDNF mRNA. However, none of the molecules investigated significantly changed the level of BDNF mRNA in neurons (Table 2).

The effects of the same molecules on NGF mRNA in hippocampal cultures were not reliable, as it was not possible to produce pure neuronal cultures without contamination by small numbers of astrocytes; thus, the weak and inconsistent effects on NGF mRNA in these cultures may result from a small number of contaminating astrocytes.

\section{Regulation of NGF and BDNF $m R N A s$ in cultured astrocytes}

In confirmation of previous experiments (Lindholm et al., 1990; Spranger et al., 1990), IL-1 and TGF- $\beta$ both produce a marked increase in NGF mRNA levels. However, they did not affect the very low levels of BDNF mRNA (Fig. 6). Thus, unlike the situation in cultured hippocampal neurons, BDNF and NGF mRNAs in cultured astrocytes are regulated in distinctly different manners. In contrast to observations in hippocampal neurons, the basal levels of BDNF mRNA in control astrocytes were very low and could not be increased by any other growth factor tested, such as FGF, TGF- $\beta$, or epidermal growth factor (EGF; data not shown). Both BDNF and NGF mRNA levels were increased by TPA, ionomycin, and forskolin (Fig. 6). However, forskolin increased BDNF mRNA levels substantially more than those of NGF mRNA. As in hippocampal neurons, forskolin cnhanced the stimulatory effect of the calcium ionophore inomycin on BDNF mRNA levels in cultured astrocytes, suggesting that BDNF regulation might involve similar mechanisms in both neurons and glia cells.

\section{Regulation of NGF and BDNF $m R N A$ levels in astrocytes by neurotransmitters}

With the knowledge that neuronal activity regulates BDNF and NGF mRNA expression in neurons and since astrocytes also 


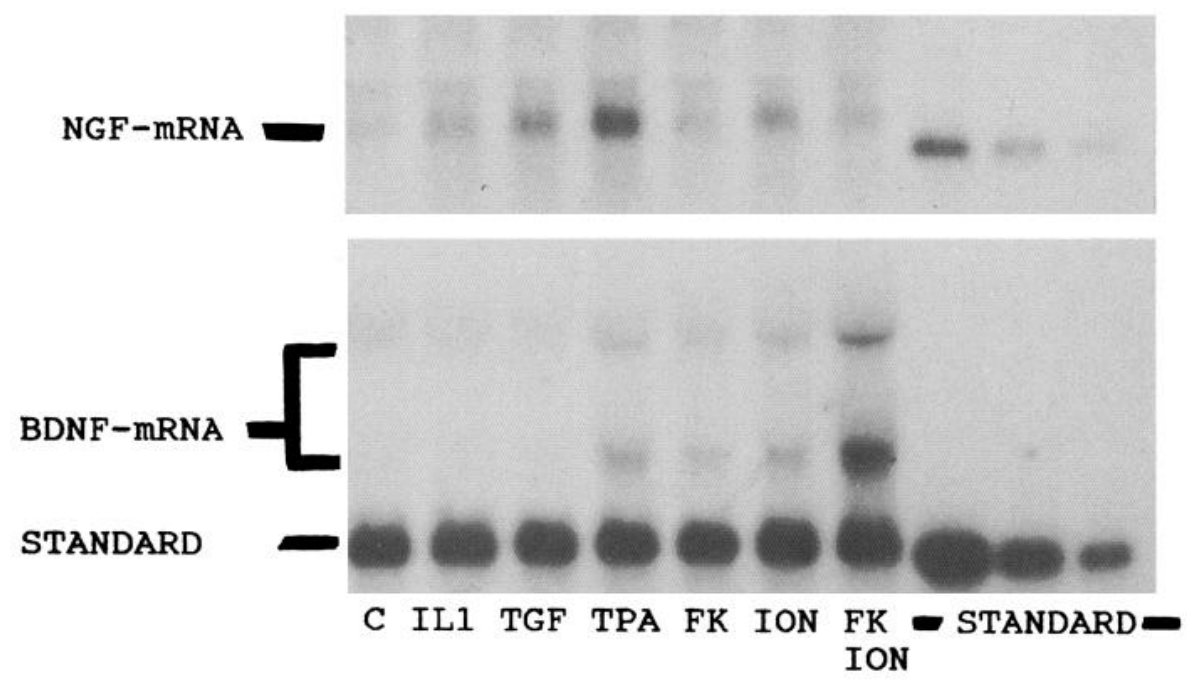

Figure 6. The effect of various growth factors and agents on NGF and BDNF mRNA levels in astrocytes. Confluent astrocytes were incubated for $4 \mathrm{hr}$ in the absence $(C)$ or presence of various additions: IL-1 (IL1; $30 \mathrm{U} / \mathrm{ml})$; TGF$\beta 1(T G F ; 4 \mathrm{ng} / \mathrm{ml})$; TPA $(100 \mathrm{ng} / \mathrm{ml})$; forskolin $(F K ; 20 \mu \mathrm{M})$; ionomycin (ION; $1 \mu \mathrm{g} / \mathrm{ml}$ ). Total cellular RNA was extracted and analyzed by Northern blot analysis in the upper panel. The $1.3 \mathrm{~kb}$ band represents NGF mRNA, whereas the lower panel represents the two mRNA transcripts for BDNF. express neurotransmitter receptors, we investigated a series of physiological transmitters or their synthetic analogs on cultured astrocytes. Norepinephrine significantly increased BDNF mRNA levels in astrocytes (Fig. 7). Dopamine and to a lesser extent epinephrine also increased BDNF mRNA (data not shown). Glutamate alone had no effect on BDNF mRNA, but it potentiated the effect of norepinephrine (Fig. 7). Quisqualic acid, which activates both ionotropic and metabotropic glutamate receptors, exhibited effects similar to glutamate (not shown). Norepinephrine also increased the levels of NGF mRNA in cultured astrocytes, but this effect appeared to be dependent on the batch of serum used (see Discussion). In contrast, histamine, 5-HT, and carbachol did not influence the expression of either BDNF or NGF mRNA in cultured astrocytes under our experimental conditions (data not shown).

\section{Discussion}

The goal of the present investigation was to compare the regulation of BDNF and NGF in primary cultures of hippocampal neurons and brain astrocytes. The investigations were confined to the determination of the mRNA of the two neurotrophins, as a sufficiently sensitive and specific immunoassay for BDNF protein is not yet available.

In agreement with previous experiments (Zafra et al., 1990, 1991), BDNF and NGF mRNA levels in cultured hippocampal neurons were regulated in a similar manner, although some differences were observed. In contrast, the regulation of BDNF and NGF mRNAs in cultured astrocytes proved to be distinctly different.

\section{Differences between the regulation of BDNF and NGF $M R N A$ in hippocampal neurons}

Although the regulation of BDNF and NGF mRNAs show many similarities both in vitro and in vivo (Zafra et al., 1990, 1991; present results), there are also some clear differences: the basal levels of NGF mRNA both in primary cultures of brain neurons and in brain tissue in vivo are 20-30 times lower than those of BDNF mRNA (Hofer et al., 1990; Zafra et al., 1990, 1991). Moreover, the distribution of NGF mRNA in the rodent brain is generally more restricted both under normal conditions and after stimulation by kainic acid or limbic seizures (Gall and Isackson, 1989; Ballarín et al., 1991; Ernfors et al., 1991; Gall et al., 1991: Isackson et al., 1991). For instance, after systemic kainic acid administration or induction of limbic seizure by the stimulation of entorhinal cortex, BDNF mRNA levels in the hippocampus are markedly increased both in the granule cells of the dentate gyrus and in the pyramidal neurons of the CA1CA3 regions (Ballarín et al., 1991; Ernfors et al., 1991; Isackson et al., 1991). In contrast, the changes in NGF mRNA are restricted to the granule cells of the dentate gyrus. Neurons expressing NGF mRNA scattered in the pyramidal cell layer, the stratum oriens, and the hilus do not appear to be responsive to kainic acid (Gall et al., 1991; E. Castrén, unpublished observations). In the cerebellum, BDNF mRNA is expressed in the granular cell layer (Hofer et al., 1990), whereas the presence of NGF mRNA could not be unambiguously demonstrated by in situ hybridization (Bandtlow et al., 1990). In addition to the differences in the basal levels and the different patterns of expression after systemic stimulation, the increase in the BDNF mRNA after injection of kainic acid in vivo is absolutely and relatively larger than that of NGF mRNA both in hippocampus and cortex (Zafra et al., 1990). An additional difference between the regulation of NGF and BDNF mRNA is their regulation by glucocorticoids in vivo and in primary cultures of rat hippocampus. Glucocorticoids and higher concentrations of mineralocorticoids increase NGF mRNA both in vivo and in vitro (Lind-

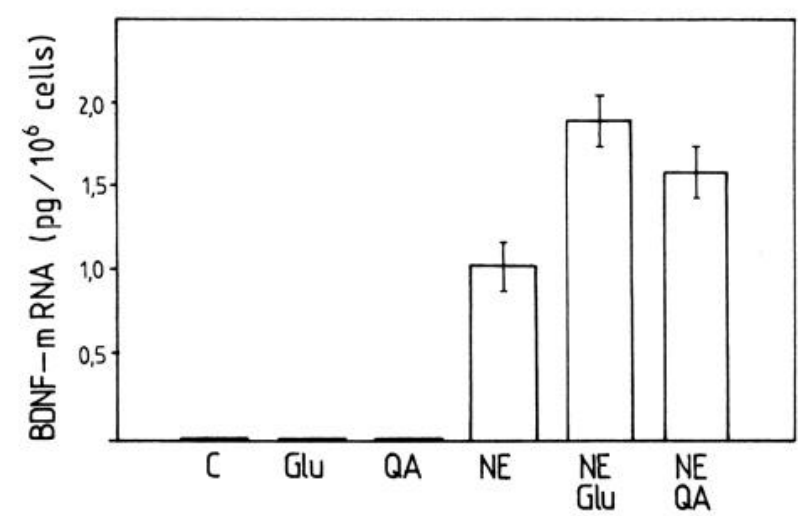

Figure 7. The effect of norepinephrine and glutamate agonists on BDNF mRNA levels in astrocytes. Cells were incubated for $4 \mathrm{hr}$ in the presence of $0.5 \mathrm{~mm}$ glutamate $(G l u), 25 \mu \mathrm{M}$ quisqualate $(Q A), 25 \mu \mathrm{M}$ norepinephrine $(N E)$, or norepinephrine with glutamate or quisqualate. RNA was extracted and analyzed as described in Materials and Methods. Values represent the mean \pm SEM of three experiments. 
holm et al., 1992a). Under the same experimental conditions, there is no detectable effect on BDNF mRNA levels (Lindholm et al., 1992a).

\section{Effect of various cytokines on the levels of BDNF and NGF $m R N A s$ in primary cultures of hippocampal neurons}

After previous experiments had shown that a series of lymphokines and cytokines produce a strong increase in NGF mRNA in cultured astrocytes (Lindholm et al., 1990; Spranger et al., 1990; Yoshida and Gage 1991, 1992), we investigated the effect of the same molecules on the levels of BDNF and NGF mRNAs in hippocampal cultures. All factors that markedly increased amounts of NGF mRNA in astrocyte cultures produced no change in BDNF mRNA levels in hippocampal cultures. The effects of the factors on NGF mRNA levels in the latter cultures were not absolutely clear in that small and inconsistent increases in the levels of NGF mRNA were seen. These small increases could be attributed to the response of the contaminating nonneuronal cells. This would also explain the results reported by Friedman et al. (1990) showing that IL-1 increases NGF mRNA in mixed cultures from hippocampus.

\section{Regulation of BDNF and NGF $m R N A$ levels in neuronal cultures of rat hippocampus: involvement of calcium and $c A M P$}

The increase in both BDNF and NGF mRNA levels in hippocampal neurons following high-potassium depolarization or addition of kainic acid depends on calcium influx. On the one hand, the effects of depolarization and kainic acid can be mimicked by calcium ionophores, and on the other, the increase in BDNF mRNA levels initiated by these treatments can be abolished in a dose-dependent manner by nifedipine. Nifedipine is thought predominantly to block voltage-gated L-type calcium channels, and the effects of both kainic acid and high potassium on calcium influx are mediated by a voltage-gated mechanism. However, recent experiments have demonstrated that, depending on the relative unit composition of the non-NMDA glutamate receptors (Hollmann et al., 1991), these ligand-gated channels regulate not only the flux of monovalent, predominantly sodium, ions but also divalent calcium ions. The complete blockade of the kainic acid-mediated BDNF mRNA increase and, at higher concentrations, the reduction of the basal levels of BDNF mRNA by nifedipine raise the question of whether nifedipine also blocks the ligand-gated calcium influx via the non-NMDA glutamate receptors.

The calcium influx-induced by kainic acid seems to be mediated by the calcium/calmodulin-dependent protein kinase. This is supported by the fact that W7 and calmidazolium, compounds that block calmodulin (Van Belle, 1981; Hidaka et al., 1991), block the kainic acid-induced increase in BDNF mRNA. Moreover $\mathrm{H} 7$, a protein kinase inhibitor that predominantly blocks protein kinase C (Hidaka et al., 1991), did not interfere with the kainic acid-mediated increase in BDNF mRNA.

In view of the fact that a variety of transmitter substances and neuropeptides regulate CAMP in positive or negative manners, we investigated the effect of forskolin on the levels of BDNF and NGF mRNAs. In neuronal cultures, forskolin increased the NGF mRNA levels about 2.5-fold, whereas there was only a slight effect on BDNF mRNA. However, the effects of the calcium ionophor Bay-K8644 and ionomycin on BDNF mRNA were markedly potentiated by forskolin. Kainic acid alone did not change the levels of cAMP; neither was the effect of kainic acid affected by the cAMP antagonist $\left(R_{p}\right)$-cAMP, which displaces cAMP from the regulatory unit of protein kinase A without activating it (O'Brian et al., 1982). Thus, the regulation of BDNF and NGF mRNA levels by kainic acid does not seem to involve cAMP directly. However, the potentiating effect of forskolin is interesting considering that in integrated neuronal systems, neuropeptides and transmitter substances, which regulate cAMP, may modulate the predominantly glutamate-mediated increase in BDNF and NGF mRNA levels in neurons.

\section{Comparison between the regulation of $B D N F$ and $N G F$ IRNA in primary culture of astrocytes}

In contrast to the many similarities in the regulation of BDNF and NGF mRNA in hippocampal neurons, the regulation for these two neurotrophins in primary cultures of astrocytes is in many respects distinctly different. NGF mRNA levels are increased by a variety of cytokines, such as IL-1, EGF, FGF, and the most potent TGF- $\beta$ (Lindholm et al., 1990; Spranger et al., 1990, Yoshida and Gage, 1991, 1992). None of these molecules had any detectable effect on BDNF mRNA levels. In this context, it is of interest to note that there is a distinct difference not only between the regulation of NGF mRNA in neurons and astrocytes, but also between astrocytes, Schwann cells, and fibroblasts (Lindholm et al., 1988; Matsuoka et al., 1991). For instance, TGF- $\beta$ is by far the strongest inducer of NGF mRNA in astrocytes (Lindholm et al., 1990), whereas it has no effect on NGF mRNA levels in primary cultures of fibroblasts and Schwann cells (Matsuoka et al., 1991). Indeed, in Schwann cells TGF- $\beta$ abolishes the increases in NGF mRNA mediated by other means (Matsuoka et al., 1991).

Norepinephrine, which under our experimental conditions had only a small effect on NGF mRNA in astrocytes, markedly increased the extremely low levels of BDNF mRNA in unstimulated astrocytes. The fact that not only norepinephrine but also forskolin initiated an increase in BDNF mRNA levels in astrocytes indicates that these effects are mediated by cAMP.

In agreement with our previous experiments (Spranger et al., 1990 ), neither $\beta$-agonists, protein kinase $A$ activation by nonhydrolyzable derivatives of cAMP, nor activation of adenyl cyclase by forskolin produced a consistent increase in NGF mRNA levels in astrocytes. This is in contrast to the observations of Schwartz and Mishler (1990), who reported an increase in NGF mRNA, not only in C6 glioma cells but also in primary cultures of astrocytes. We did observe a small increase in NGF mRNA by norepinephrine with some but not all batches of serum that we used, which could explain the discrepancy between our results and those of Schwartz and Mishler (1990). It has been reported that different batches of serum may influence expression of voltage-gated calcium channels in primary astrocytes (Barres et al., 1989). In agreement with these observations, Yoshida and Gage (1992) have recently reported that under defined conditions, cAMP increases NGF mRNA only in the presence of basic FGF.

In conclusion, the regulation of the levels of BDNF and NGF mRNAs in hippocampal neurons in many respects shows a high degree of similarity both in vitro and in vivo. However, there are also distinct differences, in particular their rcgulation by glucocorticoids (Lindholm et al., 1992b). Both BDNF and NGF mRNA levels are regulated by calcium influx, which seems to act via calcium/calmodulin-dependent protein kinases, which are additionally modulated by cAMP via protein kinase $A$. These effects of cAMP might be of considerable importance for the modulatory role by other transmitter systems and neuropeptides that activate adenyl cyclase or interfere with its activation. In 
contrast to the high degree of similarity between NGF and BDNF mRNA regulation in neurons, the regulation of these two mRNA species in astrocytes was in many respects different. The observations made in astrocyte cultures may be of importance in pathophysiological situations. Thus, after brain injury, there is an increase in the expression of growth factors, such as FGF, IL-1, and TGF- $\beta$ (Giulian and Lachman, 1985; Finklestein et al., 1988; Lindholm et al., 1992b), all of which regulate NGF expression. In agreement with the present data, the expression of NGF but not of BDNF is increased after a stab injury to the cerebral cortex (Lindholm et al., 1992b).

\section{References}

Ayer-LeLièvre C, Olson L, Ebendal T, Seiger $\AA$, Persson H (1988) Expression of the $\beta$-nerve growth factor gene in hippocampal neurons. Science 240:1339-1341.

Ballarín M, Emfors P, Lindefors N, Persson H (1991) Hippocampal damage and kainic acid injection induce a rapid increase in mRNA for BDNF and NGF in the rat brain. Exp Neurol 114:35-43.

Bandtlow CE, Meyer M, Lindholm D, Spranger M, Heumann R, Thoenen H (1990) Regional and cellular codistribution of interleukin$1 \beta$ and nerve growth factor mRNA in the adult rat brain: possible relationship to the regulation of nerve growth factor synthesis. J Cell Biol 111:1701-1711.

Barde Y-A (1991) The nerve growth factor family. Prog Growth Factor Res 2:237-248.

Barres BA, Chun LLY, Corey DP (1989) Calcium current in cortical astrocytes: induction by cAMP and neurotransmitters and permissive effect of serum factors. J Neurosci 9:3169-3175.

Brewer GJ, Cotman CW (1989) Survival and growth of hippocampal neurons in defined medium at low density: advantages of a sandwich culture technique or low oxygen. Brain Res 494:65-74.

Chomczynski P, Sacchi N (1987) Single-step method of RNA isolation by acid guanidium-thiocyanate-phenol-chloroform extraction. Anal Biochem 162:156-159.

Ernfors P, Ibáñez CF, Ebendal T, Olson L, Persson H (1990a) Molecular cloning and neurotrophic activities of a protein with structural similarities to nerve growth factor: developmental and topographical expression in the brain. Proc Natl Acad Sci USA 87:5454-5458.

Frnfors P, Wetmore C, Olson L, Persson H (1990b) Identification of cells in rat brain and peripheral tissues expressing mRNA for members of the nerve growth factor family. Neuron 5:511-526.

Ernfors P, Bengzon J, Kokaia Z, Persson H, Lindvall O (1991) Increased levels of messenger RNAs for neurotrophic factors in the brain during kindling epileptogenesis. Neuron 7:165-176.

Finklestein SP, Apostolides PJ, Caday CG, Prosser J, Philips MF, Klagsbrun M (1988) Increased basic fibroblast growth factor (bFGF) immunoreactivity at the site of focal brain wounds. Brain Res 460:253259.

Friedman WJ, Lärkfors L, Ayer-LeLièvre C, Ebendal T, Olson L, Persson $H$ (1990) Regulation of $\beta$-nerve growth factor expression by inflammatory mediators in hippocampal cultures. J Neurosci Res 27: 374-382.

Furukawa S, Furukawa Y, Satoyoshi F, Hayashi K (1986) Synthesis and secretion of nerve growth factor by mouse astroglial cells in culture. Biochem Biophys Res Commun 136:57-63.

Gall CM, Isackson PJ (1989) Limbic seizures increase neuronal production of messenger RNA for nerve growth factor. Science 245:758761 .

Gall CM, Murray K, Isackson PJ (1991) Kainic acid-induced seizures stimulate increased expression of nerve growth factor mRNA in rat hippocampus. Mol Brain Res 9:113-123.

Giulian D, Lachman LB (1985) Interleukin-1 stimulates astroglial proliferation after brain injury. Science 228:497-499.

Heumann R, Thoenen $H$ (1986) Comparison between the time course of changes in nerve growth factor (NGF) protein levels and those of its messenger RNA in the cultured rat iris. J Biol Chem 261:92469249 .

Hidaka H, Watanabe M, Kobayashi M (1991) Properties and use of $\mathrm{H}$-series compounds as protein kinase inhibitors. Methods Enzymol 201:328-340.

Hofer M, Pagliusi SR, Hohn A, Leibrock J, Barde Y-A (1990) Regional distribution of brain-derived neurotrophic factor mRNA in the adult mouse brain. EMBO J 9:2459-2464.

Hollmann M, Hartley M, Heinemann S (1991) $\mathrm{Ca}^{2+}$ permeability of KA-AMPA-gated glutamate receptor channels depends on subunit composition. Science 252:851-853.

Isackson PJ, Huntsman MM, Murray KD, Gall CM (1991) BDNF mRNA expression is increased in adult rat forebrain after limbic seizures: temporal patterns of induction distinct from NGF. Neuron 6:937-948.

Lindholm D, Heumann R, Hengerer B, Thoenen H (1988) Interleukin 1 increases stability and transcription of mRNA encoding nerve growth factor in cultured rat fibroblasts. J Biol Chem 263:16348-16351.

Lindholm D, Hengerer B, Zafra F, Thoenen H (1990) Transforming growth factor- $\beta 1$ stimulates expression of nerve growth factor in the rat CNS. Neuroreport 1:9-12.

Lindholm D, Castrén E, Hengerer B, Zafra F, Berninger B, Thoenen $H$ (1992a) Differential regulation of nerve growth factor (NGF) in neurons and astrocytes by glucocorticoid hormones. Eur $J$ Neurosci 4: 404-410.

Lindholm D, Castrén E, Kiefer R, Zafra F, Thoenen H (1992b) Transforming growth factor- $\beta 1$ in the rat brain: increase after injury and inhibition of astrocyte proliferation. J Cell Biol, in press.

Lindsay RM (1979) Adult rat brain astrocytes support survival of both NGF-dependent and NGF-insensitive neurons. Nature 282:80-82.

Lu B, Yokoyama M, Dreyfus CF, Black IB (1991) NGF gene expression in actively growing brain glia. J Neurosci 11:318-326.

Maisonpierre PC, Belluscio L, Friedman B, Alderson RF, Wiegand SJ, Furth ME, Lindsay RM, Yancopoulos GD (1990) NT-3, BDNF, and NGF in the developing rat nervous system: parallel as well as reciprocal patterns of expression. Neuron 5:501-509.

Matsuoka I, Meyer M, Thoenen H (1991) Cell-type-specific regulation of nerve growth factor (NGF) synthesis in non-neuronal cells: comparison of Schwann cells with other cell types. J Neurosci 11:31653177.

O'Brian CA, Roczniak SO, Bramson HN, Baraniak J, Stec WJ, Kaiser ET (1982) A kinetic study of interactions of $\left(R_{p}\right)$ - and $\left(S_{p}\right)$-adenosine cyclic $3^{\prime}, 5^{\prime}$-phosphorothiates with type II bovine cardiac muscle adenosine cyclic $3^{\prime}, 5^{\prime}$-phosphate dependent protein kinase. Biochemistry $21: 4371-4376$

Phillips HS, Hains JM, Laramee GR, Rosenthal A, Winslow JW (1990) Widespread expression of BDNF but not NT3 by target areas of basal forebrain cholinergic neurons. Science 250:290-294.

Schwartz JP, Mishler K (1990) $\beta$-Adrenergic receptor regulation, through cyclic AMP, of nerve growth factor expression in rat cortical and cerebellar astrocytes. Cell Mol Neurobiol 10:447-457.

Spranger M, Lindholm D, Bandtlow C, Heumann R, Gnahn H, NäherNoe M, Thoenen H (1990) Regulation of nerve growth factor (NGF) synthesis in the rat central nervous system: comparison between the effects of interleukin- 1 and various growth factors in astrocyte cultures and in vivo. Eur J Neurosci 2:69-76.

Thoenen $H$ (1991) The changing scene of neurotrophic factors. Trends Neurosci 14:165-170.

Van Belle H (1981) R24571: a potent inhibitor of calmodulin activated enzymes. Cell Calcium 2:483-494.

Wetmore C, Ernfors P, Persson H, Olson L (1990) Localization of brain-derived neurotrophic factor mRNA to neurons in the brain by in situ hybridization. Exp Neurol 109:141-152.

Whittemore SR, Friedman PL, Larhammer D, Persson H (1988) Rat $\beta$-nerve growth factor sequence and the site of synthesis in the adult hippocampus. J Neurosci Res 20:403-410.

Yoshida K, Gage FH (1991) Fibroblast growth factors stimulate nerve growth factor synthesis and secretion by astrocytes. Brain Res 538: 118-126.

Yoshida K, Gage FH (1992) Cooperative regulation of nerve growth factor synthesis and secretion in fibroblasts and astrocytes by fibroblast growth factor and other cytokines. Brain Res 569:14-25.

Zafra F, Hengerer B, Leibrock J, Thoenen H, Lindholm D (1990) Activity dependent regulation of BDNF and NGF mRNAs in the rat hippocampus is mediated by non-NMDA glutamate receptors. EMBO J 9:3545-3550.

Zafra F, Castrén E, Thoenen H, Lindholm D (1991) Interplay between glutamate and gamma-aminobutyric-acid transmitter systems in the physiological regulation of brain-derived neurotrophic factor and nerve growth factor synthesis in hippocampal neurons. Proc Natl Acad Sci USA 88:10037-10041. 